\title{
Two new species of Halysioncum Caira, Marques, Jensen, Kuchta et Ivanov, 2013 (Cestoda, Diphyllidea) from Indo-Pacific rays of the genus Aetomylaeus Garman (Myliobatiformes, Myliobatidae)
}

\author{
Verónica A. Ivanov ${ }^{1}$ and Janine N. Caira ${ }^{2}$ \\ ${ }^{1}$ Laboratorio de Helmintología, Departamento de Biodiversidad y Biología Experimental, Facultad de Ciencias Exactas y \\ Naturales, Universidad de Buenos Aires, Buenos Aires, Argentina; \\ ${ }^{2}$ Department of Ecology \& Evolutionary Biology, University of Connecticut, Storrs, Connecticut, USA
}

\begin{abstract}
Recent collections of cestode parasites from two species of the myliobatid genus Aetomylaeus Garman from several localities in the Pacific Ocean resulted in the discovery of two new species of Halysioncum Caira, Marques, Jensen, Kuchta et Ivanov, 2013. Halysioncum gibsoni sp. n. from Aetomylaeus maculatus (Gray) in the South China Sea off Borneo differs from all of its congeners in having the following combination of characters: 27 apical hooks (14 type A and 13 type B hooks), 11-12 lateral hooklets, 22-28 spines per column on the cephalic peduncle, testes distributed in a single column and an internal seminal vesicle. Halysioncum arafurense sp. n., recovered from Aetomylaeus cf. nichofii 2 (sensu Naylor et al. 2012b) in the Arafura Sea off the Wessel Islands, Northern Territory, Australia, can be distinguished from its congeners based on the following combination of characters: 23 apical hooks (12 type A and 11 type B hooks), the number of lateral hooklets (9-11), the number of spines per column on the cephalic peduncle (20-24), the number and distribution of the testes (13-15 testes in two irregular columns), and the distribution of vitelline follicles (interrupted dorsally at the level of the ovarian lobes). Both species represent the first verified records of diphyllideans from eagle rays of the genus Aetomylaeus and formally extend the host associations of diphyllideans to include a third genus of Myliobatiformes. The myliobatiforms are indeed an understudied group of available hosts for diphyllideans and represent interesting target hosts if the diversity of diphyllidean tapeworms is to be fully estimated and understood.
\end{abstract}

Keywords: tapeworms, parasites, morphology, taxonomy, elasmobranchs, South China Sea, Arafura Sea

The generic boundaries of the Diphyllidea were recently reassessed by Caira et al. (2013a) on the basis of the results of a phylogenetic analysis of molecular data. As a consequence, several species originally assigned to Echinobothrium van Beneden, 1849 were transferred to the new genera Coronocestus Caira, Marques, Jensen, Kuchta et Ivanov, 2013 and Halysioncum Caira, Marques, Jensen, Kuchta et Ivanov, 2013, resulting in a more narrowly defined concept of Echinobothrium. Coronocestus was defined as including species bearing a corona of spines on the region of the scolex anterior to the bothria and posterior to the apical organ armature, and Halysioncum as including species with lateral hooklets arranged in a continuous band (Caira et al. 2013a).

This left only species with lateral hooklets arranged in clusters on either side of the dorsal and ventral apical hooks in Echinobothrium. This new diphyllidean classification reinforces the diagnostic value of scolex features for the distinction among genera and species noted by previous authors (Campbell and Andrade 1997, Ivanov and Campbell 1998a, Tyler 2006).

Unfortunately, complete scolex armature information is lacking for several species, which have consequently been considered either as species inquirendae or nomina nuda. Most of the problematic species (see Kuchta and Caira 2010) were described from elasmobranchs in the Indo-Pacific, masking the overall diversity of diphyllideans in that region. Nevertheless, valid diphyllidean species are well represented in the Indo-Pacific, with 26 having been reported from a diverse array of hosts (Carcharhiniformes, Myliobatiformes, Rajiformes and Rhinopristiformes) from that region. Curiously, to date, no diphyllideans have been reported from myliobatiforms in that area, despite the fact that several species of Myliobatis Cuvier harbour species of Halysioncum in the eastern Pacific (Ivanov and Campbell 1998b, Tyler and Caira 1999) and Atlantic (Euzet 1951, Williams and Campbell 1980) oceans.

Address for correspondence: V.A. Ivanov, Laboratorio de Helmintología, Departamento de Biodiversidad y Biología Experimental, Facultad de Ciencias Exactas y Naturales, Universidad de Buenos Aires. Instituto de Biodiversidad y Biología Experimental y Aplicada, IBBEA-CONICET Ciudad Universitaria, pabellón 2, piso 4, Lab. 52. C1428EHA, Buenos Aires, Argentina. Phone: +54 1145763300 ext. 332 ; Fax: +54 11 4576 3384; E-mail: ivanov@bg.fcen.uba.ar 
Recent collections of cestodes from two species of the myliobatiform genus Aetomylaeus Garman collected from several localities in the Western Pacific Ocean resulted in the discovery of two new species of Halysioncum, which are described below. They represent the first verified records of diphyllideans from myliobatids of the genus Aetomylaeus.

\section{MATERIALS AND METHODS}

Specimens of elasmobranchs belonging to two species of $A e-$ tomylaeus were examined. One specimen of Aetomylaeus maculatus (Gray) (host field number BO178) was collected from the South China Sea off Sematan, Borneo during May 2003 by a local trawl fisherman. One specimen of Aetomylaeus cf. $n i-$ chofii 2 (Bloch et Schneider) (sensu Naylor et al. 2012b) (host field number NT51) was collected from the Arafura Sea, off the Wessel Islands, Northern Territory, Australia in November 1999 by the commercial trawler FV Ocean Harvest. In each case, the spiral intestine was removed, opened with a longitudinal midventral incision extending to the centre of the lumen of the spiral intestine, to expose the upper and lower surfaces of each chamber, and fixed in $10 \%$ formalin in the field. Spiral intestines were transported to the lab in individual whirl-pack bags, where they were transferred to $70 \%$ ethanol for storage.

Specimens prepared for light microscopy were hydrated in a graded ethanol series, stained with Harris' haematoxylin, dehydrated in a graded ethanol series, cleared in methyl salicylate, and mounted in Canada balsam on glass slides under coverslips. Specimens prepared for scanning electron microscopy (SEM) were hydrated in a graded ethanol series, postfixed in $1 \%$ osmium tetroxide overnight at room temperature, dehydrated in a graded ethanol series, dried using hexamethyldisilazane, mounted on stubs with carbon tape, coated with gold in a Thermo VG Scientific Polaron SC 7630 and examined with a Philips XL 30 scanning electron microscope at the Museo Argentino de Ciencias Naturales.

Measurements include the range followed in parentheses by the mean, standard deviation, number of worms examined (n) and total number of observations when more than one measurement per worm was taken $(n)$. All measurements are in micrometres unless otherwise stated. Microthrix terminology follows Chervy (2009). Hook formulae and hook symmetry follow Tyler (2006) as modified by Kuchta and Caira (2010). Figures were drawn with the aid of a drawing tube attached to a Zeiss Axioskope microscope.

Museum abbreviations used are as follows: IPCAS, Institute of Parasitology, Academy of Sciences of the Czech Republic, České Budějovice, Czech Republic; LRP, Lawrence R. Penner Collection, Department of Ecology \& Evolutionary Biology, University of Connecticut, Storrs, Connecticut; MZUM(P), Muzium Zoologi, Universiti Malaya, Kuala Lumpur, Malaysia; QM, Queensland Museum, Brisbane, Australia; SBC, Sarawak Biodiversity Center, Sarawak, Malaysia; USNPC, U.S. National Parasite Collection, Beltsville, Maryland.

Additional information and images of each host specimen can be obtained by entering the host specimen number (e.g. BO178, NT51) in the host specimen database at www.elasmobranchs.tapewormdb.uconn.edu. The elasmobranch classification used follows Naylor et al. (2012a) and the elasmobranch taxonomy follows Naylor et al. (2012b). Host specimen identifications were verified using sequence data generated for the protein-coding gene NADH2 (see Naylor et al. 2012b).

\section{RESULTS}

Halysioncum gibsoni sp. n.

Figs. 1-17

Diagnosis (based on 16 specimens: five mature specimens, three incomplete mature specimens, seven immature specimens and one observed using SEM): Worms apolytic, $3.15-4.35 \mathrm{~mm}(3.90 \pm 0.46 \mathrm{~mm}, \mathrm{n}=5)$ long; greatest width $175-240(208 \pm 25, \mathrm{n}=5)$ at level of scolex or terminal proglottid; proglottids acraspedote, 5-7 (6 \pm 1 , $\mathrm{n}=5$ ) in number (Fig. 2).

Scolex consists of scolex proper and cephalic peduncle, 375-710 $(517 \pm 98, \mathrm{n}=14)$ in length (Figs. 1, 2, 8). Scolex proper 187-300 $(236 \pm 28, \mathrm{n}=14)$ long, $175-240$ (205 $\pm 21, \mathrm{n}=13$ ) wide, composed of armed apical organ and two bothria (Figs. 1,8). Apical organ armature consists of one dorsal and one ventral group of $27(n=4)$ large hooks flanked on each side by a continuous row of 11-12 $(\mathrm{n}=3)$ smaller lateral hooklets (Figs. 1, 3, 4, 8). Each dorsoventral group of hooks arranged in two rows, consisting of one anterior row of 14 type A hooks (numbered 1 through 14 in Fig. 3) and one posterior row of 13 type B hooks (numbered 1' through 13' in Fig. 3).

Hook formula $\{(11-12) 14 / 13\}$; apical hooks type $\mathrm{A}$ and $\mathrm{B}$ gradually increase in length towards centre of group, with type B hook symmetry (Fig. 3). Type A and B hooks differ in morphology; each row of hooks covered with tissue, with tips of prongs free.

Apical hooks (see Fig. 3 for hook numbers) range in length from 25-36 (31 $\pm 4, \mathrm{n}=8)$ (type A hooks 1 and $14)$ to $93-115(105 \pm 7, n=8)$ (type B hook $\left.7^{\prime}\right)$. Hooklets 10-20 $(16 \pm 4, \mathrm{n}=11)$ long (Fig. 4). Bothria oval, 135-232 $(179 \pm 30, \mathrm{n}=20, n=12)$ long, $150-212(178 \pm 21, \mathrm{n}=20$, $n=12$ ) wide (Figs. 1, 8). Cephalic peduncle 225-500 (328 $\pm 89, \mathrm{n}=15)$ long, $75-100(85 \pm 10, \mathrm{n}=15)$ wide at base, armed with eight longitudinal columns of 22-28 (25 $\pm 2, \mathrm{n}=15, n=24)$ spines (Figs. 1, 2, 5); spines with triradiate bases, 7-70 long ( $32 \pm 25, \mathrm{n}=15, n=27)$, decrease in length posteriorly (Fig. 5).

Apex of scolex covered with capilliform and papilliform filitriches (Fig. 9). Distal bothrial surfaces with conspicuous central triangular region covered with acicular and papilliform filitriches (Figs. 10, 11); remainder of distal bothrial surfaces (lateral and posterior regions) covered with densely packed trifurcate spinitriches with long digits (Figs. 10-12). Proximal bothrial surfaces covered with papilliform filitriches and densely packed palmate spinitriches with 3-4 digits anteriorly (Fig. 13); spinitriches longer, with more digits posteriorly, i.e. 7-9 digits in middle region (Fig. 14), 6-7 digits in posterior region (Fig. 15). Border between distal and proximal bothrial surfaces marked by abrupt change in microthrix type, 


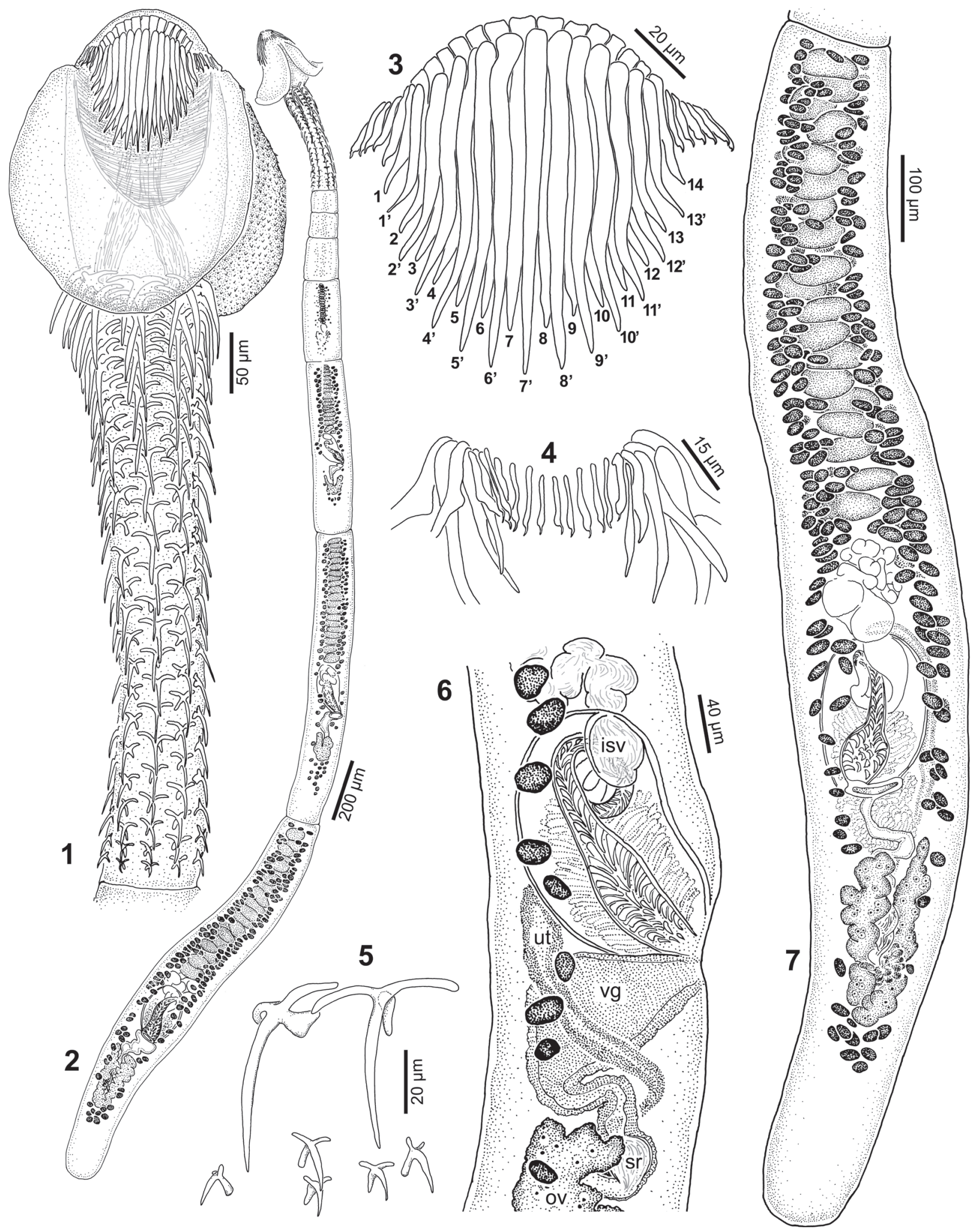

Figs. 1-7. Halysioncum gibsoni sp. n. Fig. 1. Scolex, dorsoventral view (holotype, MZUMP 2013.32). Fig. 2. Entire worm (paratype, USNPC 106974). Fig. 3. Apical hooks, dorsoventral view (holotype, MZUMP 2013.32). Fig. 4. Continuous row of lateral hooklets (paratype, USNPC 106974). Fig. 5. Detail of spines on the cephalic peduncle (holotype, MZUMP 2013.32). Fig. 6. Detail of terminal genitalia in lateral view (paratype, USNPC 106974). Fig. 7. Mature proglottid in ventral view (holotype, MZUMP 2013.32). Abbreviations: isv - internal seminal vesicle; ov - ovary; sr - seminal receptacle; ut - uterus; vg - vagina ; 1-14 - type A hooks; 1 '-14' - type B hooks. 


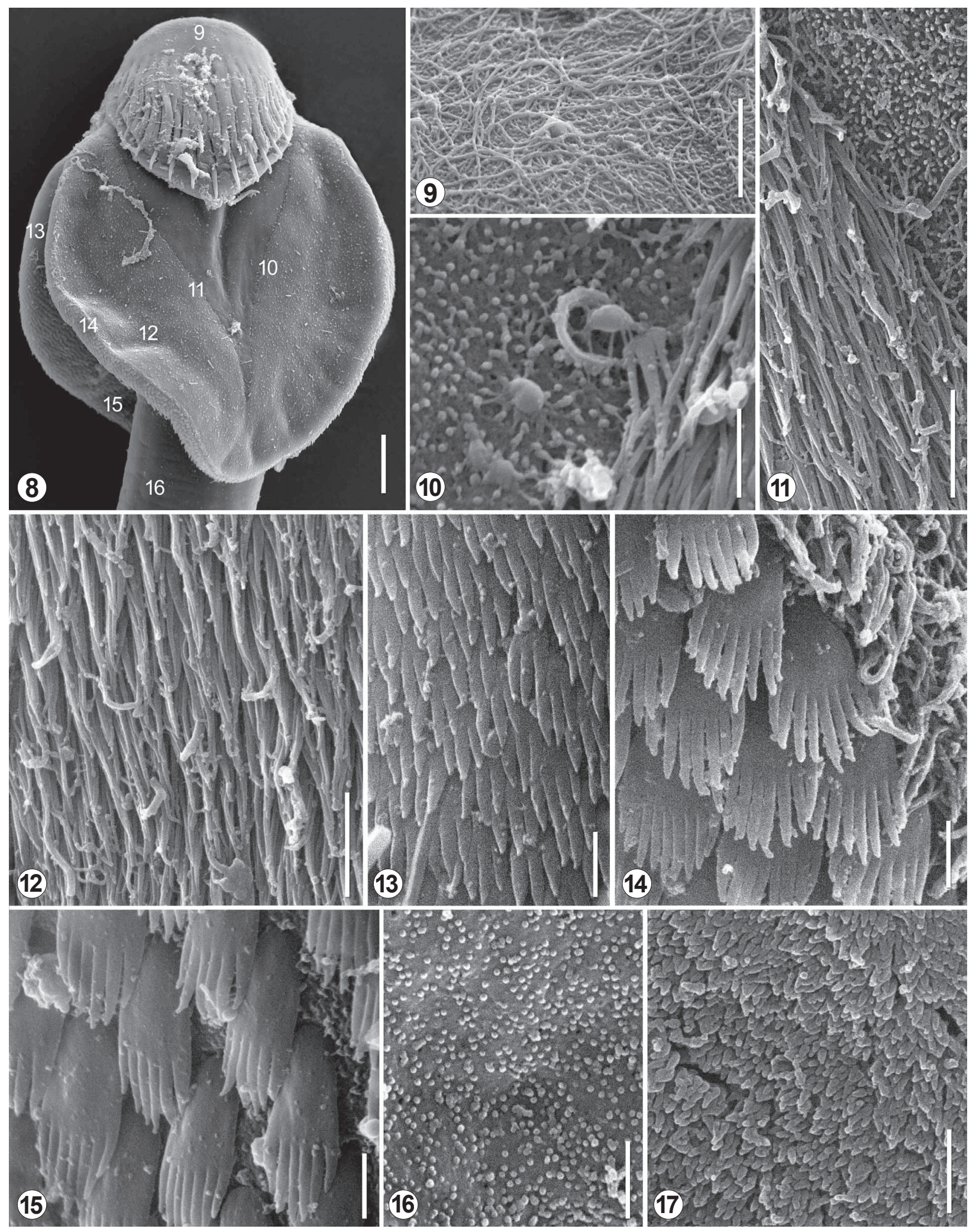

Figs. 8-17. Halysioncum gibsoni sp. n., scanning electron micrographs. Fig. 8. General view of scolex proper, dorsoventral view. Small numbers indicate locations of details shown in Figs. 9-16. Fig. 9. Surface of apex of scolex. Fig. 10. Detail of trifurcate spinitriches on lateral region of distal bothrial surface. Fig. 11. Border between central and lateral regions of distal bothrial surface. Fig. 12. Lateral region of distal bothrial surface. Fig. 13. Proximal bothrial surface, anterior region. Fig. 14. Border between distal and proximal bothrial surface, middle region. Fig. 15. Proximal bothrial surface, posterior region. Fig. 16. Surface of cephalic peduncle. Fig. 17. Surface of mature proglottid. Scale bars: Fig. $8=25 \mu \mathrm{m}$; Figs. 9, 11, $12=2 \mu \mathrm{m}$; Figs. 10, 13-17= $1 \mu \mathrm{m}$. 
from trifurcate to palmate spinitriches (Fig. 14). Cephalic peduncle covered with papilliform filitriches (Fig. 16). Strobila with acicular filitriches (Fig. 17).

Immature proglottids 4-6 $(5 \pm 1, \mathrm{n}=5)$ in number, initially wider than long, becoming longer than wide with maturity (Fig. 2). Only one mature proglottid per strobila observed in mature specimens; mature proglottid longer than wide, 1 100-1670 (1364 $\pm 234, \mathrm{n}=5)$ long, $157-210(188 \pm 22, \mathrm{n}=5)$ wide, length to width ratio 6-11: $1(7 \pm 2)$.

Testes 18-22 $(19 \pm 1, \mathrm{n}=5)$ in number, 55-88 (71 \pm 10 , $\mathrm{n}=5, n=10)$ long, $25-45(33 \pm 6, \mathrm{n}=5, n=10)$ wide, arranged in one column in anterior half of proglottid (Figs. 2, 7), one row deep in cross-section. Vas deferens extensive, highly coiled (Figs. 6, 7). Cirrus-sac oval, 150-380 (212 $\pm 95, \mathrm{n}=5)$ long, $105-133(119 \pm 11, \mathrm{n}=5)$ wide; containing cirrus covered with large spinitriches 17-20 long, glandular cells and internal seminal vesicle (Figs. 6, 7).

Ovary H-shaped, bilobed in cross-section, 100-113 $(106 \pm 7, \mathrm{n}=5)$ in maximum width; ovarian lobes 113-230 $(177 \pm 52, \mathrm{n}=5)$ long, posteriorly overlapped (Figs. 2, 7). Mehlis' gland 35-65 (48 $\pm 14, n=4)$ in width, posterior to ovarian isthmus and seminal receptacle (Fig. 7). Vagina enlarged terminally, maximum diameter 100, muscular wall 10 thick, covered distally by gland cells, opens posterior to cirrus-sac in midventral common genital pore at about $38-42 \%(40 \pm 2 \%, n=5)$ of proglottid length from posterior margin of proglottid, descends to ovarian isthmus, forms conspicuous seminal receptacle between ovarian lobes (Figs. 6, 7). Vitelline follicles in two lateral bands; each band consists of 1-2 dorsal and 1-2 ventral columns of follicles, which extend throughout proglottid length, becoming less dense at level of cirrus-sac and ovary (Figs. 6, 7); follicles 13-27 $(19 \pm 4, \mathrm{n}=5, n=20)$ long, $10-35(19 \pm 7, \mathrm{n}=5, n=20)$ wide. Gravid proglottids and eggs not observed.

Type host: Mottled eagle ray, Aetomylaeus maculatus (Gray) (Chondrichthyes, Myliobatiformes, Myliobatidae) (No. BO178).

Site of infection: Spiral intestine.

Type locality: Off Sematan, Sarawak, Malaysia, South China Sea, Pacific Ocean (0148'16"N, 10946'47"E).

Specimens deposited: Holotype (MZUM[P] 2013.32), four paratypes (MZUM[P] 2013.33-36), three paratypes (LRP 8059-8061), two paratypes (IPCAS C-636), one paratype (SBC-P-00065), four paratypes (USNPC 106974), specimens examined with SEM retained in the collection of the first author, voucher of one of the specimens examined with SEM deposited in LRP (8062).

Etymology: This species honours Dr. David Gibson, for his dedicated service to the global community of parasite taxonomists in his masterful role as the long time editor of Systematic Parasitology.

Remarks. Among the 13 valid species of Halysioncum recognized by Caira et al. (2013), H. megacanthum
(Ivanov et Campbell, 1998) and H. nataliae (Kuchta et Caira, 2010) exhibit an apical hook formula that overlaps with that of $H$. gibsoni sp. n. (i.e. $\{(12) 14 / 13\},\{(10-14)$ $14 / 13-15\}$ vs $\{(11-12) 14 / 13\}$, respectively). Halysioncum gibsoni is readily distinguished from $H$. nataliae in that its testes are arranged in a single, rather than two, columns and in that its left and right columns of vitelline follicles converge, rather than remain separate, posterior to the ovary. With respect to $H$. megacanthum, the new species bears conspicuously fewer spines per column on the cephalic peduncle (22-28 vs 38-43), a greater number of testes (18-22 vs 13-15), and is a smaller species, with a total length of only $1.71-3.10$ (vs 3.10-4.35) mm.

\section{Halysioncum arafurense sp. $\mathrm{n}$.}

Figs. 18-37

Description (based on 12 mature specimens: 11 whole mounts and one observed with SEM): Worms apolytic, $1.05-2.80 \mathrm{~mm}(1.91 \pm 0.52 \mathrm{~mm}, \mathrm{n}=11)$ long; greatest width 145-285 $(204 \pm 54, \mathrm{n}=9)$ at level of scolex or terminal proglottid; proglottids acraspedote, 4-7 (5 \pm 1 , $\mathrm{n}=10$ ) in number (Fig. 18).

Scolex consists of scolex proper and cephalic peduncle, 400-495 (434 $\pm 36, \mathrm{n}=9)$ in length (Figs. 18, 19, 25, 26). Scolex proper 150-215 (201 $\pm 14, \mathrm{n}=10)$ long, $125-170$ $(145 \pm 17, \mathrm{n}=7)$ wide, composed of armed apical organ and two bothria (Figs. 19, 26). Apical organ armature consists of one dorsal and one ventral group of $23(n=6)$ large hooks flanked on each side by a continuous row of 9-11 (n= 5) smaller lateral hooklets (Figs. 19, 21, 22, 26, 27). Each dorsoventral group of hooks arranged in two rows, consisting of one anterior row of 12 type A hooks (numbered 1 through 12 in Fig. 21) and one posterior row of 11 type B hooks (numbered 1' through 11' in Fig. 21).

Hook formula $\{(9-11) 12 / 11\}$; apical hooks type B gradually increase in length towards centre of group, with type B hook symmetry (Fig. 21). Type A and B hooks differ in morphology; each row of hooks covered with tissue, with tips of prongs free.

Apical hooks (see Fig. 21 for hook numbers) range in length from 31-52 (42 $\pm 7, \mathrm{n}=7)$ (type A hooks 1 and 12) to $65-85(74 \pm 7, \mathrm{n}=7)$ (type B hook 6'). Hooklets decreasing slightly in length laterally, $10-31(21 \pm 6, \mathrm{n}=20)$ long, possess conspicuous protuberance on proximal surface of posterior half (Fig. 22).

Bothria oval, $80-170(145 \pm 26, \mathrm{n}=11)$ long, $125-170$ $(151 \pm 17, \mathrm{n}=9)$ wide (Figs. 19, 25, 26). Cephalic peduncle 118-275 (219 $\pm 59, \mathrm{n}=10)$ long, 78-177 (100 \pm 30 , $\mathrm{n}=9$ ) wide at base, armed with eight longitudinal columns of 20-24 (22 $\pm 1, \mathrm{n}=9, n=18)$ spines (Figs. 19, 20, 25); spines with triradiate bases, 9-70 long (35 \pm 25 , $\mathrm{n}=10, n=20$ ), decrease in length posteriorly (Fig. 19).

Apex of scolex covered by capilliform and papilliform filitriches (Fig. 28). Distal bothrial surfaces with conspicuous central triangular region covered with papilliform filitriches (Fig. 29) interspersed with capilliform filitriches centrally (Fig. 30); remainder of distal bothrial sur- 

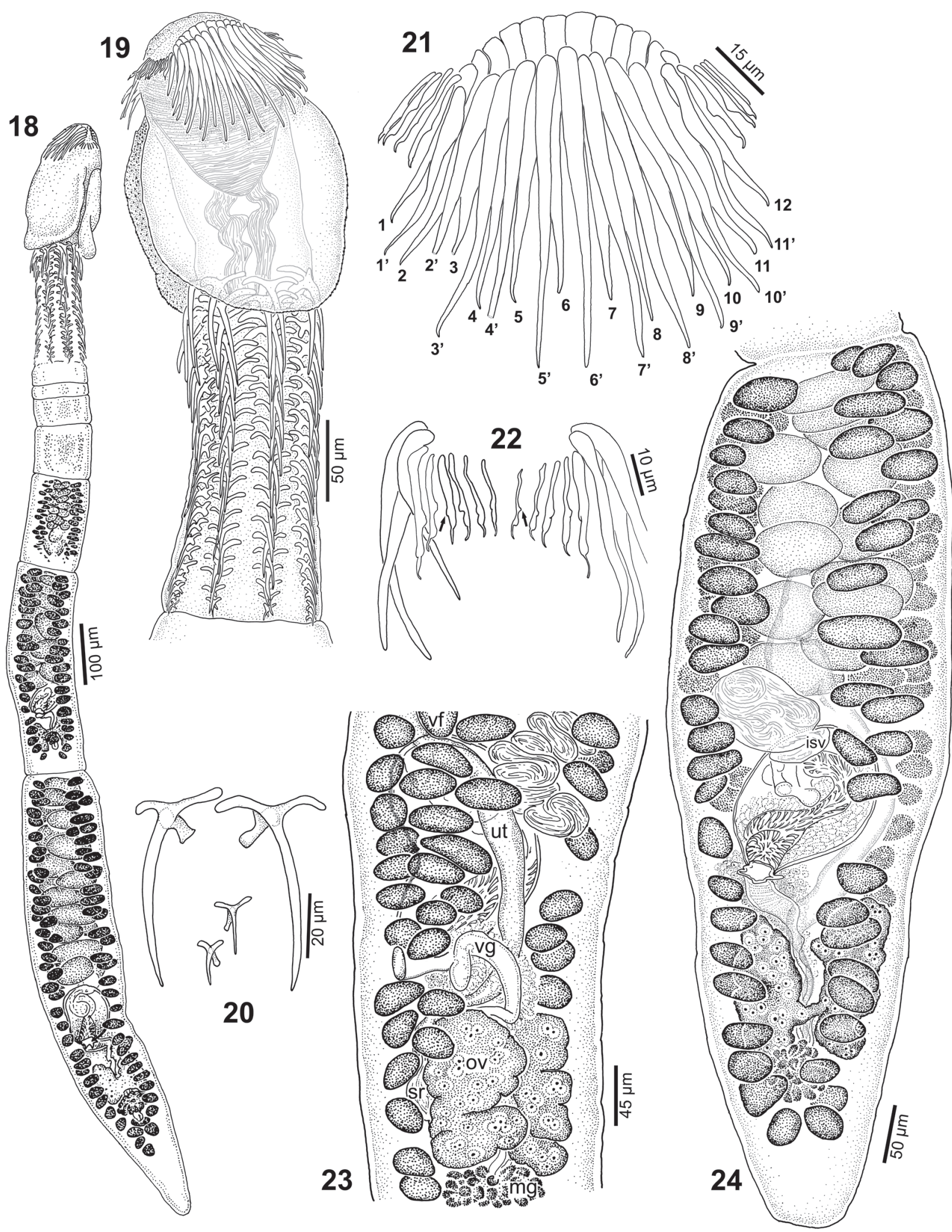

Figs. 18-24. Halysioncum arafurense sp. n. Fig. 18. Entire worm (holotype, QM G234249). Fig. 19. Scolex, dorsoventral view (paratype, QM G234250). Fig. 20. Detail of spines on the cephalic peduncle (paratype, QM G234250). Fig. 21. Apical armature, dorsoventral view (paratype, LRP 8058). Fig. 22. Continuous row of lateral hooklets, arrows indicate proximal protuberance on hooklets (paratype USNPC 106955). Fig. 23. Detail of terminal genitalia in lateral view (paratype, USNPC 106955). Fig. 24. Mature proglottid in ventral view (paratype, LRP 8058). Abbreviations: isv - internal seminal vescicle; mg - Mehlis' gland; ov - ovary; sr - seminal receptacle; ut - uterus; vf, vitelline follicle; vg - vagina ; 1-12 - type A hooks; 1'-11' - type B hooks. 

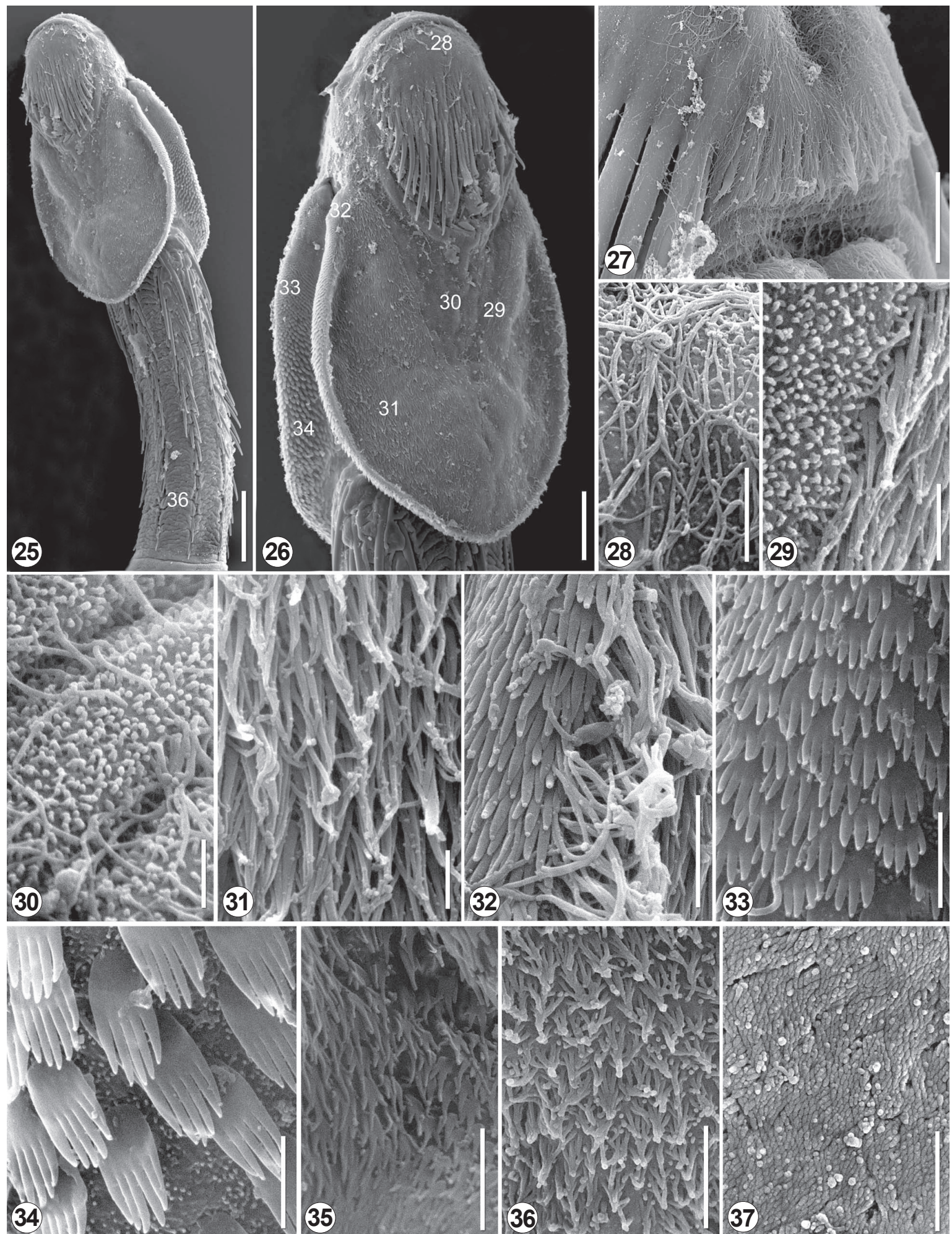

Figs. 25-37. Halysioncum arafurense sp. n., scanning electron micrographs. Fig. 25. General view of scolex, dorsoventral view. Small number indicates location of details shown in Fig. 36. Fig. 26. Scolex, dorsoventral view. Small numbers indicate locations of details shown in Figs. 28-34. Fig. 27. Detail of continuous row of lateral hooklets. Fig. 28. Surface of apex of scolex. Fig. 29. Border between central and lateral regions of distal bothrial surface. Fig. 30. Central region of distal bothrial surface. Fig. 31. Lateral and posterior region of distal bothrial surface. Fig. 32. Border between distal and proximal bothrial surface, anterior region. Fig. 33. Proximal bothrial surface, anterior region. Fig. 34. Proximal bothrial surface, posterior region. Fig. 35. Surface of scolex proper. Fig. 36. Surface of cephalic peduncle. Fig. 37. Surface of immature proglottid. Scale bars: Fig. $25=50 \mu \mathrm{m} ;$ Fig. $26=25 \mu \mathrm{m}$; Fig. $27=10 \mu \mathrm{m}$; Figs. $28,32-37=2 \mu \mathrm{m}$; Figs. $29-31=1 \mu \mathrm{m}$. 
faces (lateral and posterior regions) covered with densely packed trifurcate spinitriches with long digits (Figs. 29, 31). Proximal bothrial surfaces covered with papilliform filitriches and densely packed palmate spinitriches with 3-5 digits in anterior portion and palmate spinitriches with 5-7 digits posteriorly (Figs. 33, 34).

Border between proximal and distal bothrial surfaces marked by abrupt change in microthrix type, having band of capilliform filitriches between palmate and trifurcate spinitriches on proximal and distal surfaces, respectively (Fig. 32). Scolex proper covered by trifid spinitriches with central digit longer than lateral digits (Fig. 35). Cephalic peduncle covered with acicular filitriches (Fig. 36). Strobila covered with densely packed filitriches (Fig. 37).

Immature proglottids $3-6(4 \pm 1, \mathrm{n}=10)$ in number, initially wider than long, becoming longer than wide with maturity (Fig. 18). Mature proglottids $1-2(1 \pm 0.3, \mathrm{n}=9)$ in number, longer than wide (ratio 3-5: 1), 540-1220 $(770 \pm 212, \mathrm{n}=9)$ long, $145-285(204 \pm 54, \mathrm{n}=9)$ wide.

Testes $13-17(14 \pm 1, \mathrm{n}=11)$ in number, $70-113$ $(85 \pm 12, \mathrm{n}=11, n=16)$ long, $38-63(49 \pm 8, \mathrm{n}=11$, $n=16$ ) wide, arranged in two irregular columns from anterior margin of proglottid to anterior margin of cirrus-sac (Fig. 24), one row deep in cross section. Cirrus-sac pyriform, anterior to ovary, $75-175(131 \pm 33, \mathrm{n}=10)$ long, 70-137 (98 $\pm 23, \mathrm{n}=10)$ wide, contains cirrus covered with large spinitriches $8-15$ long and numerous gland cells, and internal seminal vesicle (Figs. 23, 24). Extensive vas deferens resembles external seminal vesicle (Fig. 24).

Ovary H-shaped in frontal view, bilobed in cross-section, with lobes anterior to ovarian isthmus longer than lobes posterior to isthmus (Fig. 24), 95-175 (120 \pm 27 , $\mathrm{n}=9$ ) wide at ovarian isthmus; ovarian lobes 80-210 $(130 \pm 42, \mathrm{n}=11)$ long. Mehlis' gland 43-70 (55 \pm 10 , $\mathrm{n}=6$ ) in width, posterior to ovary (Figs. 23, 24). Vagina enlarged terminally, maximum diameter 60, muscular wall 12 thick, surrounded distally by gland cells, opens posterior to cirrus-sac in midventral common genital pore at about $31-40 \%$ of proglottid length from posterior margin of proglottid. Vitelline follicles in two lateral bands; each band consists of 1-2 dorsal and 1-2 ventral columns of follicles, extends throughout proglottid length, with dorsal follicles interrupted at level of ovary (Fig. 23); follicles 30-65 (43 $\pm 11, \mathrm{n}=10, n=25)$ long, 20-45 (34 \pm 17 , $\mathrm{n}=10, n=25)$ wide. Gravid proglottids and eggs not observed.

Type host: Banded eagle ray, Aetomylaeus cf. nichofii 2 (sensu Naylor et al. 2012b) (Chondrichthyes, Myliobatiformes, Myliobatidae) (No. NT51).

Site of infection: Spiral intestine.

Type 1ocality: East of Wessel Islands, Northern Territory, Australia, Arafura Sea, Pacific Ocean (11 $17^{\prime} 44^{\prime \prime S}$, $\left.136^{\circ} 59^{\prime} 48^{\prime \prime} \mathrm{E}\right)$.

Specimens deposited: Holotype (QM G234249), two paratypes (QM G234250, G234251), four paratypes (LRP 8055-8058), three paratypes (USNPC 106955), two paratypes (IPCAS C-637), specimens examined with SEM retained in the collection of the senior author, voucher of one specimen examined with SEM deposited in LRP (8056).

E t y molog y: This species is named for its type locality.

Remarks. Among the 14 valid species of Halysioncum, the hook formula of $H$. arafurense sp. n. overlaps only with that of $H$. mexicanum (Tyler et Caira, 1999). These two species are readily distinguished in that, whereas the vitelline follicles of the former are interrupted dorsally at the level of the ovarian lobes, this is not the case in $H$. mexicanum. Furthermore, these two species differ in the shape of their lateral hooklets in that there is a conspicuous proximal protuberance on the hooklets of the new species that is not seen in H. mexicanum. In addition, the new species generally possesses a smaller number of spines per column on the cephalic peduncle (20-24 vs 23-40) and also smaller apical hooks (up to $85 v s 113 \mu \mathrm{m}$ long) than stated in H. mexicanum. In addition to a hook formula that differs from that seen in $H$. gibsoni $\{(9-11)$ $12 / 11\}$ vs $\{(11-12) 14 / 13\}$, this new species is smaller (1.05-2.80 vs 3.15-4.35 $\mathrm{mm}$ in total length) and bears fewer testes (13-15 vs 18-22), which are arranged in two columns rather than a single column.

\section{DISCUSSION}

Diphyllidean cestodes parasitize a wide range of elasmobranchs, most commonly, species of Carcharhiniformes, Myliobatiformes, Rajiformes and Rhinopristiformes. Among these, the selachian families Triakidae and Scyliorhinidae host the majority of diphyllidean genera (i.e. Coronocestus, Ditrachybothridium and Ahamulina Marques, Jensen et Caira, 2012). In contrast, batoids host only two genera (Echinobothrium and Halysioncum, see Kuchta and Caira 2010, Rodriguez et al. 2011, Ivanov and Caira 2012, Marques et al. 2012, Caira et al. 2013a,b), but they host the majority of diphyllidean species.

Among this group of elasmobranchs, Echinobothrium diversity is particularly high in the Rajidae, Rhinobatidae and Dasyatidae, whereas Halysioncum has a particular affinity for batoids of the families Myliobatidae and Rhinopteridae (Caira et al., 2013a). Nonetheless, to date, only six valid species of Halysioncum have been reported from myliobatids, four from species of Myliobatis, i.e. H. fautleyae (Tyler et Caira, 1999) from M. californica; $H$. megacanthum from M. goodei; and H. mexicanum from $M$. californica and M. longirostris (see Kuchta and Caira 2010), and now two from Aetomylaeus (i.e. H. gibsoni and $H$. arafurense from $A$. maculatus and $A$. cf. $n i-$ choffi 2, respectively). Among the remaining species of the Myliobatidae (see Koch et al. 2012, Naylor et al. 2012a), Aetobatus ocellatus (Kuhl) has been reported to host diphyllideans (Kuchta and Caira 2010). Southwell (1911) described E. boisii Southwell, 1911 from A. ocel- 
latus as [A. narinari (Euphrasen)] off Sri Lanka. However, it has been considered a species inquirenda by most authors (Campbell and Andrade 1997, Ivanov and Campbell 1998a, Tyler 2006, Kuchta and Caira 2010) because it was described from a single immature specimen, no diagnostic features were provided, and data on the apical armature were lacking and cannot be determined from the original figures owing to their sketchy nature (Southwell 1911 - Fig. 6a on Plate V).

Southwell (1925) later synonymized this species with E. typus van Beneden, 1849, despite the fact that E. typus is a much smaller worm (mature worms $2.0-5.6 \mathrm{~mm}$ vs immature worms $10 \mathrm{~mm}$ long). Recently, Caira et al. (2013a) transferred this species to Halysioncum on the basis of a continuous band of lateral hooklets observed in a voucher specimen collected from the type host, and also in light of its association with a myliobatid host. However, due to the uncertainty of its morphological features, $H$. boisii should remain a species inquirenda.

One additional record of a cestode from a myliobatid is also of potential relevance here. Diagonobothrium asymmetricum Shipley et Hornell, 1906 was described by Shipley and Hornell (1906) from A. maculatus (as Myliobatis maculatus) off Sri Lanka. The description is also inadequate by modern standards and was based on the scolex of a single specimen; this monotypic genus has subsequently been treated as a genus inquirendum (Wardle and McLeod 1952, Jones et al. 1994), genus incerta sedis (Yamaguti 1959) and a nomen dubium (Tyler 2006).

Euzet (1994) suggested this specimen was likely a diphyllidean that had lost its rostellar hooks and cephalic peduncle spines. In fact, diphyllideans are small, delicate worms and it is not rare to find them hookless, especially if the host is not dissected immediately after capture. Nevertheless, the specimen described as D. asymmetricum was certainly not conspecific with $H$. gibsoni, described herein from the same host species. Whereas $H$. gibsoni is a relatively small species with a maximum scolex size of $710 \mu \mathrm{m}$ long by $240 \mu \mathrm{m}$ wide, Shipley and Hornell (1906) reported $D$. asymmetricum to bear a scolex $2.3 \mathrm{~mm}$ long by $1.0 \mathrm{~mm}$ wide. As a consequence, we believe the specimens described in the present study constitute the first verified report of diphyllideans from a species of Aetomylaeus.

Based on other cestode records, at least 11 other species of myliobatids have been examined for cestodes (see Koch et al. 2012). Among these, only Pteromylaeus bovinus (Geoffroy Saint-Hilaire) has been reported to host diphyllideans; an undescribed species of Halysioncum from Pteromylaeus bovinus (Geoffroy Saint-Hilaire) was included in the molecular phylogenetic analysis of Caira et al. (2013a). Eight of the 25 species of Myliobatidae remain to be examined for cestodes of any type. The myliobatids are indeed an understudied group of available hosts for diphyllideans and represent interesting target hosts if the diversity of diphyllidean tapeworms is to be fully estimated and understood. With the exception of $H$. mexicanum and $H$. fautleyae, both reported from two host species, only one species of diphyllidean has been found in each species of myliobatid. If this pattern persists, we predict the total number of species of Halysioncum will approximately equal the number of unexamined myliobatiform species.

The species of Halysioncum parasitizing myliobatid hosts share some morphological traits. The cirrus is covered with robust spinitriches, the vagina is enlarged and dilated distally, the genital pore is anterior to the ovary, and the vitelline follicles are confluent in the posterior extremity of the proglottid (in all species but H. fautleyae, which is unique in exhibiting vitelline follicles that extend from the anterior margin of the proglottid to the anterior margin of the ovary). However, none of these traits are unique to this suite of diphyllideans.

Acknowledgments. We are grateful to Bill and Ray Passey for providing JNC with the opportunity to collect fresh samples on the FV Ocean Harvest off the Wessel Islands, and Latip Sait for allowing JNC to collect on his trawler working off Sematan. We also thank Kirsten Jensen for assisting with the collections of tapeworms from hosts in both Australia and Borneo. This work has been partly funded by grant UBACyT 2010-2012 No. 01/2511 from Universidad de Buenos Aires (Argentina), PIP 2011-2013 No. 236 from CONICET (Argentina) to VAI, NSF BS\&I grants DEB 0542846 and DEB 0542941, and NSF PB\&I grants DEB 0818696 and DEB 0818823.

\section{REFERENCES}

Caira J.N., Marques F., Jensen K., Kuchta R., Ivanov V.A. 2013a: Phylogenetic analysis and reconfiguration of genera in the cestode order Diphyllidea. Int. J. Parasitol. 43: 621-639.

Caira J.N., Pickering M., Schulman A.D., Hanessian N.J. 2013b: Two new species of Echinobothrium (Cestoda: Diphyllidea) from batoids off South Africa. Comp. Parasitol. 80: 22-32.

Campbell R.A., Andrade M. 1997: Echinobothrium raschii n. sp. (Cestoda: Diphyllidea) from Rhinoraja longi (Chondrichthyes, Rajoidei) in the Bering Sea. J. Parasitol. 83: 115-120.

Chervy L. 2009: Unified terminology for cestodes microtriches: a proposal from the participants of the International Work- shops on Cestode Systematics in 2002-2008. Folia Parasitol. 56: 199-230.

Euzet L. 1951: Echinobothrium mathiasi n. sp. (Cestoda: Diphyllidea) parasite d'une raie: Leiobatis aquila L. Bull. Soc. Zool. France 76: 182-188.

Euzet L. 1994: Order Tetraphyllidea Carus, 1863. In: L.F. Khalil, A. Jones and R.A. Bray (Eds.), Keys to the Cestode Parasites of Vertebrates, CAB International, Wallingford, pp. 149-194.

Ivanov V.A., CaIra J.N. 2012: Description of three new species of Echinobothrium (Cestoda, Diphyllidea) from Indo-Pacific elasmobranchs of the genus Glaucostegus (Rajiformes, Rhinobatidae). J. Parasitol. 98: 365-377. 
Ivanov V.A., CAmpBell, R.A. 1998a: Echinobothrium californiense n. sp. (Cestoda: Diphyllidea) from the thornback ray, Platyrhinoidis triseriata (Chondrichthyes: Rajoidei), and a key to the species in the genus. Syst. Parasitol. 40: 49-54.

Ivanov V.A., Campbell, R.A. 1998b: Echinobothrium megacanthum n. sp. (Cestoda: Diphyllidea) from the eagle ray, Myliobatis goodei Garman, 1885 (Chondrichthyes: Myliobatidae), from the Patagonian shelf of Argentina. Folia Parasitol. 45: 225-229.

Jones A., Bray R.A., Khalil L.F. 1994: Lists of genera. In: L. F. Khalil, A. Jones, and R. A. Bray (Eds.), Keys to the Cestode Parasites of Vertebrates, CAB International, Wallingford, pp. 673-677.

Koch K.R., Jensen K., Caira J.N. 2012: Three new genera and six new species of lecanicephalideans (Cestoda) from eagle rays of the genus Aetomylaeus (Myliobatiformes: Myliobatidae) from northern Australia and Borneo. J. Parasitol. 98: 175-198.

Kuchta R., Caira J.N. 2010: Three new species of Echinobothrium (Cestoda: Diphyllidea) from Indo-Pacific stingrays of the genus Pastinachus (Rajiformes: Dasyatidae). Folia Parasitol. 57: $185-196$

Marques F.P.L., Jensen K., Caira J.N. 2012: Ahamulina $n$. gen. (Cestoda: Diphyllidea) from the polkadot catshark, Scyliorhinus besnardi (Carcharhiniformes: Scyliorhinidae), off Brazil. Zootaxa 3352: 51-59.

Naylor G., Caira J.N., Jensen, K., Matthes K., White W., LAST P. 2012b: A DNA sequence based approach to the identification of shark and ray species and its implications for global elasmobranch diversity and parasitology. Bull. Am. Mus. Nat. Hist. 367: 1-262.

Naylor G., Caira J.N., Jensen, K., Rosana K.A.M., Straube N., LAKNER C. 2012a: Elasmobranch phylogeny: a mitochon-

Received 9 January 2013 drial estimate based on 595 species. In: J. Carrier, J. Musack and E. Heithaus (Eds.), The Biology of Sharks and Their Relatives. CRC Press. Boca Raton, Florida, pp. 31-56.

Rodriguez N., Pickering M., Caira J.N. 2011: Echinobothrium joshuai $\mathrm{n}$. sp. (Cestoda: Diphyllidea) from the roughnose legskate, Cruriraja hulleyi (Rajiformes: Rajidae), off South Africa. Comp. Parasitol. 78: 306-311.

Shipley A.E., Hornell J. 1906: Report on the cestode and nematode parasites from marine fishes of Ceylon. Report to the Government of Ceylon on the Pearl Oyster Fisheries of the Gulf of Manaar (Herdman), Part 5: 43-96.

Southwell T. 1911: Description of nine new species of cestode parasites, including two new genera from marine fishes of Ceylon. Ceylon Mar. Biol. Rep. 1: 216-225.

Southwell T. 1925: A monograph on the Tetraphyllidea with notes on related cestodes. Mem. Liverpool School Trop. Med. (N. S.) 2: 1-368.

Tyler G.A. 2006: A monograph on the Diphyllidea (Platyhelminthes, Cestoda). Tapeworms of Elasmobranchs. Part II. Bull. Univ. Nebr. State Mus. 20: 1-142.

Tyler G.A., Caira J.N. 1999: Two new species of Echinobothrium (Cestoda: Diphyllidea) from myliobatiform elasmobranchs in the Gulf of California, México. J. Parasitol. 85: 327-335.

Wardle R.A., McLeod J.A. 1952: The Zoology of Tapeworms. University of Minnesota Press, Minneapolis, $780 \mathrm{pp}$.

Williams A.D., CAmpBell, R.A. 1980: Echinobothrium bonasum sp. n., a new cestode from the cownose ray, Rhinoptera bonasus (Mitchill, 1815), in the western North Atlantic. J. Parasitol. 66: 1036-1038.

Yamaguti S. 1959: Systema Helminthum. Vol. 2. The Cestodes of Vertebrates. Interscience Publishers, New York, 860 pp.

Accepted 31 January 2013 